\title{
Effect of surfactant and surfactant blends on pseudoternary phase diagram behavior of newly synthesized palm kernel oil esters
}

This article was published in the following Dove Press journal:

Drug Design, Development and Therapy

31 May 2011

Number of times this article has been viewed

\author{
Elrashid Saleh Mahdi' \\ Mohamed HF Sakeena' \\ Muthanna F Abdulkarim' \\ Ghassan Z Abdullah'1,3 \\ Munavvar Abdul Sattar ${ }^{2}$ \\ Azmin Mohd Noor ${ }^{1}$ \\ 'Department of Pharmaceutical \\ Technology, ${ }^{2}$ Department of \\ Physiology, School of Pharmaceutical \\ Sciences, Universiti Sains Malaysia, \\ Minden, Penang, Malaysia; ${ }^{3}$ Department \\ of Pharmaceutical Technology, \\ International Medical University, Bukit \\ Jalil, Kuala Lumpur, Malaysia
}

Background: The purpose of this study was to select appropriate surfactants or blends of surfactants to study the ternary phase diagram behavior of newly introduced palm kernel oil esters.

Methods: Nonionic surfactant blends of Tween ${ }^{\circledR}$ and Tween ${ }^{\circledR} / \operatorname{Span}^{\circledR}$ series were screened based on their solubilization capacity with water for palm kernel oil esters. Tween ${ }^{\circledR} 80$ and five blends of Tween ${ }^{\circledR} 80 / \operatorname{Span}^{\circledR} 80$ and Tween ${ }^{\circledR} 80 / \operatorname{Span}^{\circledR} 85$ in the hydrophilic-lipophilic balance (HLB) value range of 10.7-14.0 were selected to study the phase diagram behavior of palm kernel oil esters using the water titration method at room temperature.

Results: High solubilization capacity was obtained by Tween ${ }^{\circledR} 80$ compared with other surfactants of Tween ${ }^{\circledR}$ series. High HLB blends of Tween ${ }^{\circledR} 80 / \operatorname{Span}^{\circledR} 85$ and Tween ${ }^{\circledR} 80 / \operatorname{Span}^{\circledR} 80$ at HLB 13.7 and 13.9, respectively, have better solubilization capacity compared with the lower HLB values of Tween ${ }^{\circledR} 80 / \operatorname{Span}^{\circledR} 80$. All the selected blends of surfactants were formed as waterin-oil microemulsions, and other dispersion systems varied in size and geometrical layout in the triangles. The high solubilization capacity and larger areas of the water-in-oil microemulsion systems were due to the structural similarity between the lipophilic tail of Tween ${ }^{\circledR} 80$ and the oleyl group of the palm kernel oil esters.

Conclusion: This study suggests that the phase diagram behavior of palm kernel oil esters, water, and nonionic surfactants is not only affected by the HLB value, but also by the structural similarity between palm kernel oil esters and the surfactant used. The information gathered in this study is useful for researchers and manufacturers interested in using palm kernel oil esters in pharmaceutical and cosmetic preparation. The use of palm kernel oil esters can improve drug delivery and reduce the cost of cosmetics.

Keywords: phase diagram, palm kernel oil esters, nonionic surfactants, microemulsions

\section{Introduction}

Malaysia is the world's leading producer of palm oil from the fruit of the oil palm (Elates guineensis Jacq). Two types of oils are extracted from the fruit, ie, palm oil (from the mesocarp of the fruit) and palm kernel oil (from the nut of the palm fruit). The two types of oils differ greatly in their properties, due to variations in the composition of their triglycerides, glycerol, and fatty acids, even though they are derived from the same plant. Variations in the composition of palm oil and palm kernel oil influence their physical properties and uses. The unique composition of palm oils renders them versatile in various applications, such as in food, chemicals, pharmaceuticals, cosmetics, and personal care products. Palm oil is mainly composed of monounsaturated, long-chain palmitic fatty acids, and in the food industry is
Correspondence: Munavvar Abdul Sattar Department of Physiology, School of Pharmaceutical Sciences, Universiti Sains Malaysia, Minden, I 1800 Pinang, Pulau Pinang, Malaysia Tel +6046577888

Fax +6046570017

Email munavvar@usm.my 
interchangeable with olive oil, ${ }^{1}$ while palm kernel oil is rich in medium-chain saturated lauric and myristic fatty acids, is mainly used in oleochemicals, cosmetics, and surfactants, and is almost interchangeable with coconut oil. ${ }^{1}$

Research bodies in Malaysia, including Malaysia Palm Oil Board, Palm Oil Research Institute of Malaysia, and Universiti Putra Malaysia, are actively modifying palm oils to give them improved properties and broaden their applications, including synthesizing esters from palm oil and palm kernel oil. Palm oil and palm kernel oil are used to produce palm oil esters and palm kernel oil esters, respectively, using oleyl alcohol and lipase enzyme as a catalyst. ${ }^{2-5}$ The reaction is a relatively simple and inexpensive one..$^{2-5}$ Esterification of palm oil and palm kernel oil into palm oil esters and palm kernel oil esters has grown due to the possibility of obtaining a wide variety of high quality natural products under mild reaction conditions, utilizing selective and environmentally friendly enzyme substrate biocatalysts. ${ }^{4}$

Palm kernel oil comprises saturated lauric fatty acid (C12:0), which represents $44 \%$ of the composition of palm kernel oil, followed by saturated myristic acid (C14:0) at $14 \%$, and unsaturated oleic acid (C18:1) at 17\%., ${ }^{1,6}$ Oils containing lauric acid are significantly different from other commercial oils and fats. They are hard and brittle solids at ambient temperatures, and melt abruptly and completely at temperatures slightly below body temperature. ${ }^{7}$ Palm kernel oil contains lauric acid, has low levels of unsaturation, and consequently is more stable to oxidation than other commercially available oils. ${ }^{1,7}$ Lauric acid-based oils, such as coconut and palm kernel oil, have many uses in the pharmaceutical and cosmetic industries. ${ }^{8}$ Studies have shown that medium-chain lauric and myristic fatty acids are potent agents for increasing penetration of active ingredients into the skin. ${ }^{9}$

Palm kernel oil esters are synthesized as carriers for active ingredients of pharmaceutical and cosmetic formulations by transesterification using the RMIM lipozyme as a catalyst. ${ }^{4}$ Palm kernel oil esters are rich in oleyl laurate ester (54.1\%), oleyl myristrate ester (13.9\%), oleyl oleate (6.4\%), and oleyl palmitate $6.2 \%{ }^{4}$ (Figure 1). These fatty acid esters have several advantages in comparison with nonesterified fatty acids, including better storage and thermal stability characteristics, good fat-soluble properties, excellent wetting behavior at the interface, and are less greasy, nonirritating, and nontoxic., ${ }^{4,10,11}$ Palm kernel oil esters have overall physicochemical properties, ie, refractive index, iodine value, saponification value, acid value, density, and melting points, that are lower than

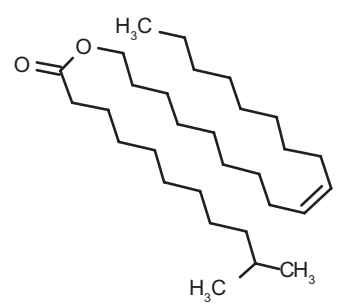

A Oleyl laurate $(54.1 \%)$

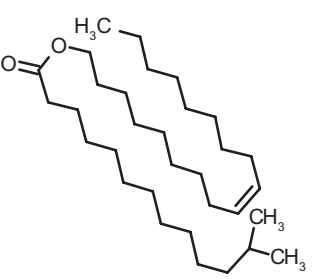

B Oleyl myristrate (13.9\%)
Figure I Chemical structure of the main palm kernel oil esters.

for palm kernel oil. ${ }^{4}$ Furthermore, palm kernel oil esters can penetrate the skin very well. The chemical structures of the main constituents, ie, oleyl laurate ester and oleyl myristrate ester, are shown in Figure 1. These desirable properties have important implications for their use in pharmaceutical, cosmetic, and personal care products. ${ }^{2}$ Importantly, palm kernel oil esters are quite similar to but less expensive than jojoba oil, which is used widely in pharmaceuticals and cosmetics. The use of cheaper palm kernel oil esters can reduce the cost of many of these products.

We have studied mixtures of palm kernel oil esters, nonionic surfactants (the Tween ${ }^{\circledR}$ and Span $^{\circledR}$ series) and their water phase diagram behavior. The phase diagrams were constructed based on observation and microscopic identification of the dispersion type noted for the mixtures produced, using an aqueous titration method described elsewhere, ${ }^{12}$ with slight modification, at ambient temperature $\left(26 \pm 2^{\circ} \mathrm{C}\right)$. The nonionic surfactant series, ie, Tween ${ }^{\circledR}$ 80, Tween ${ }^{\circledR} 60$, Tween $^{\circledR} 20$, and Tween ${ }^{\circledast} 85$, and the $\operatorname{Span}^{\circledR}$ series, ie, $\operatorname{Span}^{\circledR} 80, \operatorname{Span}^{\circledR} 60, \operatorname{Span}^{\circledR} 20$, and $\operatorname{Span}^{\circledR} 85$, were chosen for screening. Generally, polyoxyethylene sorbitan mono-oleate, such as Tween ${ }^{\circledR} 80$ with a hydrophilic-lipophilic balance (HLB) value of 15.0 and sorbitan oleate or $\operatorname{Span}^{\circledR}$ 80 with an HLB value of 4.3 , were chosen for screening because they have a high degree of compatibility with other ingredients, good chemical stability, and low toxicity. ${ }^{13}$ Span $^{\circledast} 80$ is a viscous, lipophilic, emulsifying liquid agent which tends to form water-in-oil emulsions. ${ }^{14}{ }^{\text {Tween }}{ }^{\circledR} 80$ is a derivative of $\operatorname{Span}^{\circledR} 80$, but is hydrophilic in nature because the hydroxyl groups on the sorbitan ring are replaced and substituted with bulky polyoxyethylene groups. ${ }^{15}$ This substitution makes Tween ${ }^{\circledR} 80$ more soluble in water, so it tends to form oil-in-water emulsions. ${ }^{14,15}$ In Tween ${ }^{\circledR} 85$, two of the hydroxyl groups of the polyoxyethylene moiety of Tween ${ }^{\otimes}$ 80 are substituted by two lipophilic oleate tail groups to form polyoxyethylene sorbitan triaoleates. This substitution makes Tween ${ }^{\circledast} 85$ more lipophilic, with an HLB of 11.0 compared with Tween ${ }^{\circledR} 80$, which has an HLB of 15.0. Tween ${ }^{\circledR} 85$ has 
wide application in the pharmaceutical industry, owing to its good biological compatibility. ${ }^{16}$ Furthermore, Tween ${ }^{\circledR} 80$ and $\operatorname{Span}^{\circledR} 80$ are generally recognized as safe, and are approved for use in a number of pharmaceutical, cosmetic, and food products because they are nonirritant and have a low potential for toxicity. ${ }^{17}$

Palm kernel oil esters were selected as the oil phase for this study because of their similarity to jojoba oil, their ready availability in Malaysia, and because they are cheaply sourced. The overall aim of this research was to identify the optimal surfactant or blend of surfactants using HLB values and then investigate the pseudoternary phase diagram behavior of mixtures of these surfactants with palm kernel oil esters and water. The pseudoternary phase diagrams were constructed in order to identify the types of dispersion systems formed by the mixtures at different concentrations of their components. These phase diagrams would provide boundary maps containing information about the surfactant(s) used and the range of oil, water, and surfactant compositions which would produce various phases or type of mixtures as a function of their component concentrations. The information generated by our pseudoternary phase behavior studies should be useful for researchers and manufacturers interested in developing dispersion systems for pharmaceutical formulations or cosmetic products.

Our interest at this time is in microemulsions, which are clear, isotropic, thermodynamically stable colloidal systems. They are formed spontaneously by the chemical energy of surfactants, combinations of surfactants, and cosurfactants upon mixing a suitable oil phase and water without any mechanical energy input. ${ }^{18}$ Microemulsions have many advantages compared with conventional emulsions, including increased drug-loading and enhanced transdermal delivery. ${ }^{16}$ The structure of microemulsions as a function of their component volumes of oil and water is generally divided into three types. ${ }^{19}$ The bicontinuous structure in which both oil and water domains exist and are separated by a surfactantrich interface layer can be joined continuously from one side of the specimen to another. This structure consists of microdroplets, either water or oil, surrounded by surfactant and dispersed, respectively, in oil or water, forming a water-in-oil or oil-in-water emulsion. Microemulsions have important applications in dermal and transdermal drug delivery. ${ }^{20}$ Specifically, water-in-oil microemulsions have potential applications in topical ocular drug delivery. ${ }^{18,21}$ The spontaneous formulation of microemulsion systems requiring a high concentration of surfactant(s) may lead to toxicity, which is considered to be a potential disadvantage of microemulsion systems. ${ }^{18}$

\section{Materials and methods} Materials

The nonionic surfactants of Tween ${ }^{\circledR}$ and $\operatorname{Span}^{\circledR}$ series used in this study were purchased from Sigma Chemical Co (St Louis, MO). Sodium benzoate was purchased from $\mathrm{R}$ and M Chemicals (Essex, UK). Palm kernel oil esters were gifted from the Department of Chemistry, Faculty of Science, Universiti Putra (Selangor, Malaysia). The distilled water used in this study was mixed with sodium benzoate in a concentration of $0.1 \%$. All other materials were used without further purification.

\section{Selection of surfactant}

Selection of surfactant is critical to obtaining the desired formulation. Each surfactant and oil has a specific HLB. The corrected HLB of the selected surfactant or blend of surfactants that match the HLB of the selected oil provides the lowest interface tension between the oil and water phases. The HLB of the selected surfactant(s) reflects the stability of the system at lower levels, and can be obtained when the HLBs of the surfactant and oil are similar. In this study, the palm kernel oil esters used were mainly composed of oleyl esters containing medium-chain lauric fatty acids (54.1\%) and myristic fatty acids (13.9\%), as shown in Figure $1 .{ }^{4}$ Oleyl alcohol is cis-9-octadecen-1-ol, a nonionic unsaturated fatty alcohol. It has many uses as a nonionic surfactant, emollient, and thickening agent in skin preparations. Palm kernel oil esters are composed of oleyl esters in which the side chains match the tail of nonionic surfactants. Therefore, nonionic surfactants were chosen to study the phase diagram behavior of palm kernel oil esters. Nonionic surfactants are also generally recognized as being safe and biocompatible, and are not affected by $\mathrm{pH}$ changes in media because they are uncharged. The nonionic surfactants shown in Tables 1 and 2 were chosen for screening to select a suitable single surfactant or pair of surfactants that would best match palm kernel oil esters. The water solubilization capacity, ie, minimum content of surfactant required to form a microemulsion system ${ }^{22}$ with palm kernel oil esters, was performed as a criterion for optimization using the water titration method. We used our solubilization results to select the best emulsifier to study the phase diagram behavior of palm kernel oil esters.

Nonionic surfactants of the Tween ${ }^{\circledast}$ series (Table 1) and palm kernel oil esters were weighed and put into a series of screwcap test tubes in the range of 0.1:0.9, 0.2:0.8, 0.3:0.7, 0.4:0.6, and 0.5:0.5 w/w g of $1 \mathrm{~g}$ per batch, mixed together, and vortexed thoroughly. Thereafter, $100 \mu \mathrm{L}(0.1 \mathrm{~g})$ of 
Table I Chosen hydrophilic nonionic surfactant for screening (Tween ${ }^{\circledR}$ series)

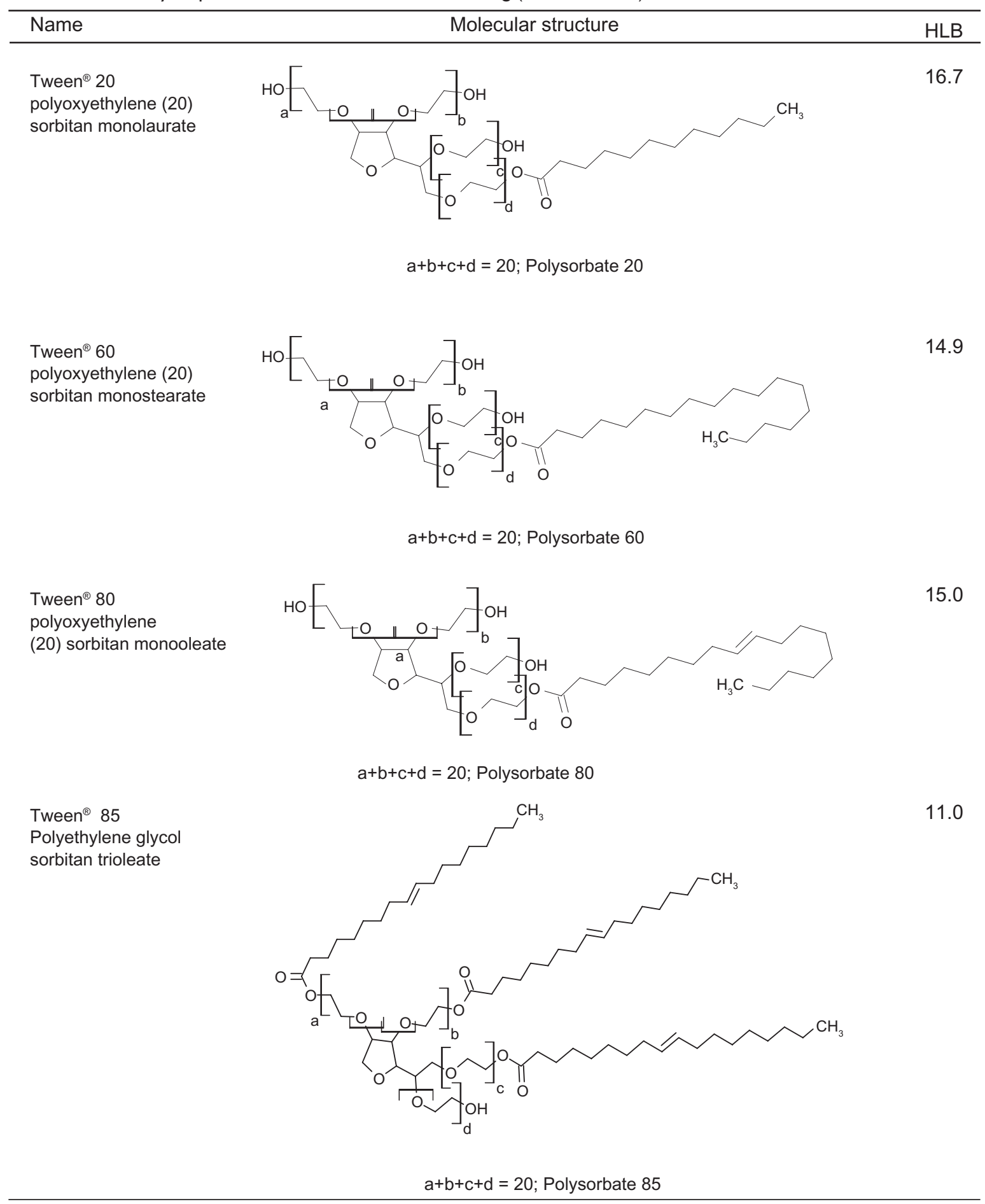

Abbreviation: HLB, hydrophilic-lipophilic balance.

distilled water containing sodium benzoate $0.1 \%$ was added to each oil-surfactant mixture in $20-25 \mu \mathrm{L}$ drops using a micropipette. After each drop of water was added, the system was vortexed for 10-20 seconds. The final mixtures, after complete addition of water, were vortexed for 2-3 minutes at room temperature. Visual observations were made, and the clarity or turbidity of each sample was recorded. The surfactant that formed a microemulsion or a clear system was selected as the surfactant that best matched palm kernel oil esters. 
Table 2 The chosen nonionic lipophilic surfactant for screening (Span ${ }^{\circledR}$ series)

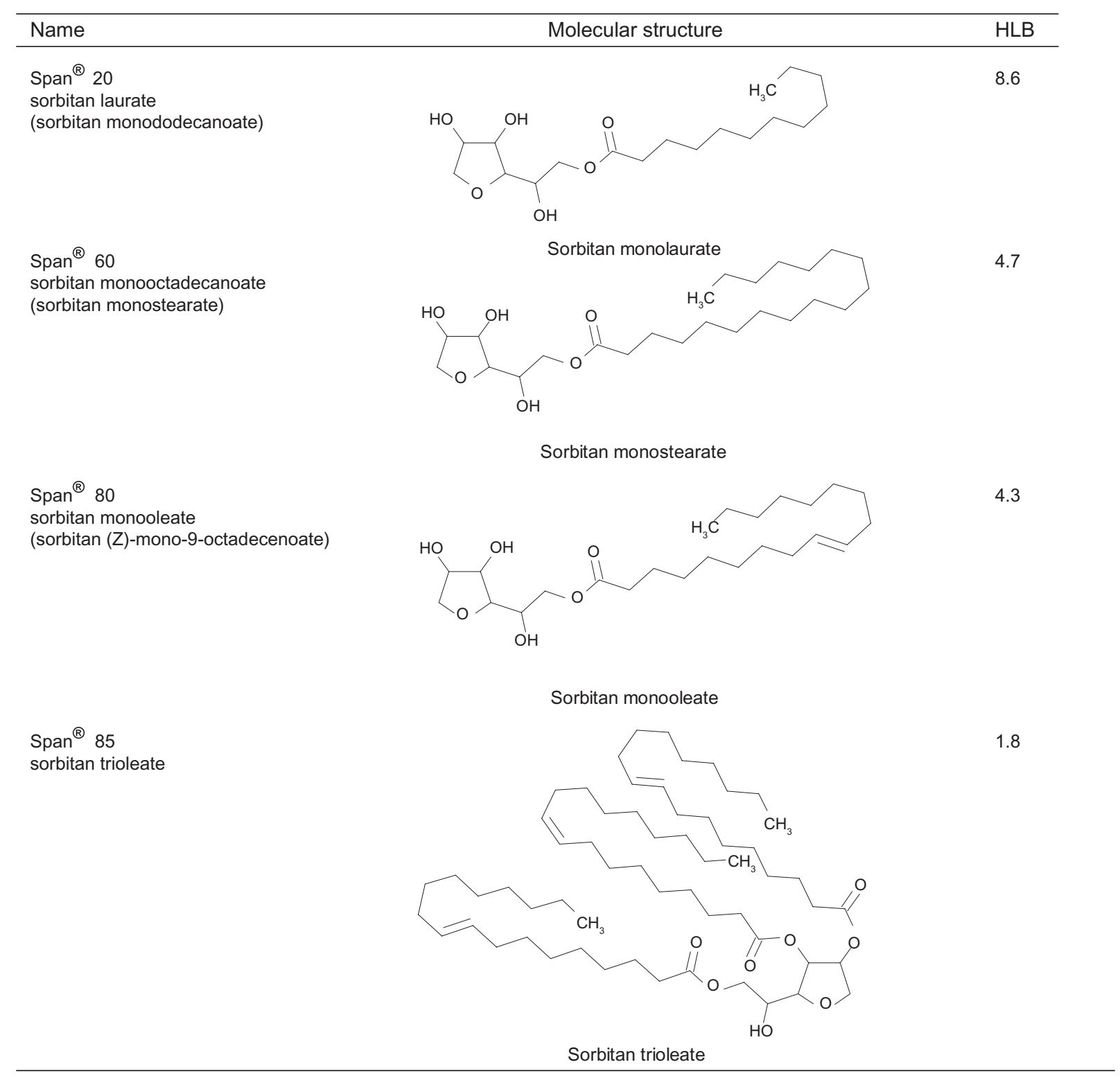

Abbreviation: HLB, hydrophilic-lipophilic balance.

\section{Selection of surfactant blend}

A blend of hydrophilic and lipophilic surfactants is needed to obtain longer stability of the dispersion phase at the lowest concentration levels. ${ }^{14,23} \mathrm{We}$ investigated blends of surfactants as well as single surfactants. We also took physical form, ie, liquid versus solid, into account in our selection of surfactant blends (Table 2). A blend of surfactants with an HLB that matches that of the oil phase will provide better solubilization and stability of the dispersion system produced. Therefore, the selection of surfactant blends at lower and higher HLB matching the HLB of oil is important in the formulation of a colloidal system.

The individual nonionic hydrophilic surfactant Tween ${ }^{\circledR}$ 80 (Table 1) was blended with the lipophilic surfactants of the $\operatorname{Span}^{\circledR}$ series (Table 2) in ratios of 3:2, 7:3, 4:1, and 9:1 $\mathrm{w} / \mathrm{w}$ to produce blends of surfactants with various HLBs in the range of 10.7-14.0. The solubilization capacities of the blends of surfactants were studied using the same method used to study other surfactants individually. The blend of surfactants forming a clear system at the minimum 
concentration (water-in-oil microemulsion) was selected as the blend that best matched the HLB of palm kernel oil esters.

\section{Construction of phase diagrams}

Phase diagrams were constructed based on the types of mixtures or dispersion systems formed when palm kernel oil ester-surfactant mixtures were serially titrated with water at ambient temperature. Various weight to weight blends of selected surfactants in the ratios of 2:3, 3:7, 1:4, 1:9, and 0:1 were produced to form surfactant mixtures with HLB values of $10.7,11.8,12.9,13.7,13.9,14.0$ and 15.0 , respectively. The palm kernel oil esters and the blend of surfactants at each HLB value were weighed separately in universal glass bottles, and were mixed and vortexed thoroughly in specific oil to surfactant ratios at $1 \mathrm{~g}$ per batch in the range of 9:1-1:9. The oil to surfactant ratios represented the first points of the titration track on the oil-surfactant axis. Each mixture was slowly titrated with aliquots of $100 \mu \mathrm{L}(0.1 \mathrm{~g})$ distilled water mixed with $0.1 \%$ sodium benzoate dropwise at a rate of $20-25 \mu \mathrm{L} /$ drop using a micropipette in a range varying from $7 \%$ to $95 \% \mathrm{w} / \mathrm{w}$, in $3 \%-7 \%$ increments. After each addition of water, the systems were vortexed for 10-20 seconds, and the final mixtures were vortexed for 2-3 minutes at room temperature. Initial visual observation of the resulting mixtures, categorized according to their physical characteristics, is shown in Table 3. Microscopic examination was made of the final mixtures to identify the type of emulsion obtained using water-soluble dyes, ie, Congo red and methylene blue (Table 3). Details of the visual observation and microscopic identification of the resulting mixtures were recorded and are shown in Table 4 (example of a mixture containing Tween ${ }^{\circledR} 80$ at HLB 15.0). The mixtures were stored for 24 hours at room temperature to achieve equilibrium. After equilibrium was reached, the final visual observation was recorded (Table 4). The results of visual observation and microscopic examination are shown

Table 3 Categories of visual observation

\begin{tabular}{ll}
\hline Category & Description \\
\hline $\begin{array}{l}\text { Microemulsions } \\
\text { Liquid crystal }\end{array}$ & $\begin{array}{l}\text { Transparent or translucent and can flow easily } \\
\text { Transparent or translucent nonflowable when } \\
\text { inverted } 90^{\circ}\end{array}$ \\
$\begin{array}{l}\text { Emulsion } \\
\text { Emollient gel or } \\
\text { cream }\end{array}$ & $\begin{array}{l}\text { Milky or cloudy and can flow easily non flowable when inverted } 90^{\circ} \\
\text { Bicontinuous phase }\end{array}$ \\
& $\begin{array}{l}\text { More than one type of dispersion exists in the } \\
\text { mixture, as indicated by the presence of more } \\
\text { than one abbreviation of dispersions }\end{array}$ \\
\hline
\end{tabular}

in Table 5 (including an example of the results for mixtures at HLB 15.0). Visual observation and microscopic examination are shown in Table 5, the percentage of the component composition is shown in Table 4 for mixtures containing Tween ${ }^{\circledR} 80$ and the results were plotted into a separate threecomponent pseudoternary phase diagram. The A vertex in the triangle phase diagram represents palm kernel oil esters, the $B$ vertex represents the surfactant, and the $C$ vertex represents the water phase. Results for mixtures containing each of the surfactant systems with other HLBs were also tabulated into tables similar to Tables 4 and 5, and these tables were used to construct the respective phase diagrams.

\section{Results and discussion Solubilization capacity}

Reverse micelle systems have been an interesting area of research in various fields of science and technology, due to their capability to solubilize water in organic solvents in the presence of surfactants. ${ }^{24}$ It is known that ethoxylated nonionic hydrophilic surfactants tend to form reverse micelles in organic media. ${ }^{25}$ The results for the reverse micelle systems in this study formed by screening Tween ${ }^{\circledR}$ series surfactants are shown in Table 6 . Tween ${ }^{\circledast} 80$ shows a high solubilization capacity compared with Tween ${ }^{\circledR} 20$, Tween ${ }^{\circledR} 60$, and Tween ${ }^{\circledR} 85$. Tween ${ }^{\circledR}$ series shown in Table 1 is structurally similar in the head group for polyoxyethylene, but differs in the tail group. Tween ${ }^{\circledast} 80$ is derived from polyoxyethylene sorbitan (head group) and oleic acid (tail group), as shown in Table 1. Tween ${ }^{\otimes} 80$ tail group is composed of unsaturated oleic acid, which is structurally different from the tail group in palm kernel oil esters, and is made up of fatty acid esters, mainly of medium-chain lauric acid and myristic acid, but is similar to the oleyl moiety of palm kernel oil esters (Figure 1). Tween ${ }^{\circledR} 80$ tail group comprises a long chain (C18) of unsaturated oleic acid, while Tween ${ }^{\circledR} 20$ is structurally composed of a medium-chain carbon tail (C12, lauric acid), the main fatty acid of palm kernel oil esters. In spite of the structural similarity between the lipophilic tails of Tween ${ }^{\circledR} 20$ and palm kernel oil esters, Tween 20 shows the lowest solubilization capacity compared with Tween ${ }^{\circledR} 80$ (Table 6). This indicates a weak interaction between the oil and surfactant from the same fatty acid derivative. Similarly, Tween ${ }^{\circledR} 60$ has lower solubilization capacity in water with palm kernel oil esters despite sharing a carbon chain tail of similar length to Tween ${ }^{\otimes} 80$, but lacks the carbon double bond at the $\mathrm{C} 9$ position in the chain in the tail group (monostearate). Therefore, the presence of the carbon double bond at position 9 in the tail group has a great effect on the solubilization 
Table 4 Example of calculation of component percentages usingl:9 oil surfactant ratio and visual observation used in the construction of phase diagram formed by Tween ${ }^{\circledR} 80$ HLB I 5.0 and palm kernel oil esters at oil to a surfactant ratio of I:9 and water (percentage of oil, surfactant, and water for other systems containing a surfactant mixture of other HLB values, and oil to surfactant blends at other ratios were calculated and tabulated in the same way)

\begin{tabular}{|c|c|c|c|c|c|c|c|}
\hline $\begin{array}{l}\text { Weight of } \\
\text { oil (g) }\end{array}$ & $\begin{array}{l}\text { Weight of } \\
\text { surfactant (g) }\end{array}$ & $\begin{array}{l}\text { Weight of } \\
\text { water added (g) }\end{array}$ & $\begin{array}{l}\text { Total } \\
\text { weight (g) }\end{array}$ & $\begin{array}{l}\% \text { of } \\
\text { oil }\end{array}$ & $\begin{array}{l}\% \text { of } \\
\text { surfactant }\end{array}$ & $\begin{array}{l}\% \text { of } \\
\text { water }\end{array}$ & $\begin{array}{l}\text { Visual observation } \\
\text { and identification }\end{array}$ \\
\hline 0.1 & 0.9 & 0.1 & I.I & 9.1 & 81.8 & 9.1 & ME BC \\
\hline 0.1 & 0.9 & 0.2 & 1.2 & 8.3 & 75 & 16.7 & ME (O/W) \\
\hline 0.1 & 0.9 & 0.3 & 1.3 & 7.7 & 69.2 & 23.1 & $\mathrm{ME}(\mathrm{O} / \mathrm{W})$ \\
\hline 0.1 & 0.9 & 0.4 & $\mathrm{I} .4$ & 7.1 & 64.3 & 28.6 & LC $(\mathrm{O} / \mathrm{W})$ \\
\hline 0.1 & 0.9 & 0.5 & 1.5 & 6.7 & 60.0 & 33.3 & LC $(\mathrm{O} / \mathrm{W})$ \\
\hline 0.1 & 0.9 & 0.6 & 1.6 & 6.2 & 56.3 & 37.5 & LC (O/W) \\
\hline 0.1 & 0.9 & 0.7 & 1.7 & 5.9 & 52.9 & 41.2 & LC (O/W) \\
\hline 0.1 & 0.9 & 0.8 & 1.8 & 5.5 & 50.0 & 44.5 & LC $(\mathrm{O} / \mathrm{W})$ \\
\hline 0.1 & 0.9 & 0.9 & 1.9 & 5.3 & 47.4 & 47.4 & LC $(\mathrm{O} / \mathrm{W})$ \\
\hline 0.1 & 0.9 & 1.0 & 2.0 & 5.0 & 45.0 & 50.0 & LC (O/W) \\
\hline 0.1 & 0.9 & I.I & 2.1 & 4.8 & 42.8 & 52.3 & LC (O/W \\
\hline 0.1 & 0.9 & 1.2 & 2.2 & 4.5 & 40.9 & 54.5 & $\mathrm{LC}(\mathrm{O} / \mathrm{W}$ \\
\hline 0.1 & 0.9 & $\mathrm{I}, 5$ & 2.5 & 4.0 & 36.0 & 60.0 & $\mathrm{ME}(\mathrm{O} / \mathrm{W})$ \\
\hline 0.1 & 0.9 & 2.0 & 3.0 & 3.3 & 30.0 & 66.7 & $\mathrm{ME}(\mathrm{O} / \mathrm{W})$ \\
\hline 0.1 & 0.9 & 5.0 & 6.0 & 1.7 & 15.0 & 83.3 & ME (O/W) \\
\hline 0.1 & 0.9 & 10.0 & 11.0 & 0.9 & 8.2 & 90.9 & $M E(O / W)$ \\
\hline 0.1 & 0.9 & 15.0 & 16.0 & 06 & 5.6 & 93.8 & ME (O/W) \\
\hline 0.1 & 0.9 & 20.0 & 21.0 & 0.05 & 4.3 & 95.2 & ME (O/W) \\
\hline
\end{tabular}

Abbreviations: LC, liquid crystal; O/W, oil in water; ME, microemulsion; BC, bicontinuous phase; HLB, hydrophilic-lipophilic balance.

capacity of Tween ${ }^{\circledR}$ series surfactants to water in palm kernel oil esters. This result shows the importance of esterification of palm kernel oil esters with oleyl alcohol because it is the source of the structural similarities between palm kernel oil esters and Tween ${ }^{\circledR} 80$ tail group. It was also shown that when the number of the oleate group increases, as in Tween ${ }^{\circledR}$ 85 , the solubilization capacity decreases. This indicates the importance of a minimum number of hydroxyl groups of polyoxyethylene in the head group configuration with the oleate group. The results of this study are consistent with those of a previous study showing that the maximum solubilization capacity of water depends upon the oxyethylene chain and the configuration of the polar head group and hydrocarbon moiety of nonionic surfactants and on type of oil. ${ }^{24}$ However, nonionic hydrophilic surfactants tend to form reverse micelle systems, ${ }^{25}$ and the HLB of a single surfactant (Tween ${ }^{\circledR}$ series) has no significant effect on the solubilization capacity. The results of this study show that the high HLB of Tween ${ }^{\circledast} 20$ (16.7) has retained the least solubilization capacity (36.4\%) compared with Tween ${ }^{\circledR} 80$ at HLB 15.0 , Tween ${ }^{\circledR} 60$ at HLB 14.9, and Tween ${ }^{\circledR} 85$ at HLB 11.0, which reached solubilization capacities of $18.2 \%, 27.3 \%$, and $27.3 \%$, respectively (Table 6 ). This is clearly shown by the solubilization capacity of Tween ${ }^{\circledR} 85$ at HLB 11.0, in which two other hydrogens in the hydroxyl groups attached to polyoxyethylene are replaced by oleate groups, and retain a stronger solubilization capacity compared with Tween ${ }^{\circledR} 20$, which has a similar head group to that of Tween ${ }^{\circledR} 80$ and Tween ${ }^{\circledR} 60$. This means that the head group of the Tween ${ }^{\circledR}$ series in single use has no effect on the solubilization capacity of these surfactants.

Our results for the solubilization capacity of blends of surfactants show that Tween ${ }^{\circledR} 80 / \mathrm{Span}^{\circledR} 85$ at HLB 13.7 has the highest solubilization capacity compared with the Tween ${ }^{\circledR}$ $80 / \operatorname{Span}^{\circledR} 80$ blend at HLB 13.9. These results indicate the importance of unsaturated trioleates because of the more lipophilic tail group that is structurally similar to the oleyl group on the palm kernel oil esters, which enables the surfactants to be well packed at the interface. Thus, these results reflect the effect of the type of surfactant blend on the solubilization capacity. It shows that high solubilization capacity can be obtained when surfactants having the lowest and highest HLB values are mixed together, as shown by the solubilization capacity result for Tween ${ }^{\circledR} 80 / \operatorname{Span}^{\circledR} 85$ compared with the Tween ${ }^{\circledR} 80 / \mathrm{Span}^{\circledR} 80$ blend (Table 6). Tween ${ }^{\circledR} 80 / \mathrm{Span}^{\circledR}$ 80 at HLB 13.9 has stronger solubilization capacity (27.3\%) compared with Tween ${ }^{\circledR} 80 / \operatorname{Span}^{\circledast} 80$ at HLB $12.8,11.8$, and 10.7, which shows the least solubilization capacity (45.4\%). This result indicates that palm kernel oil esters interact less with lipophilic surfactants or surfactant blends with lower HLB values. It also shows the importance of better selection of a surfactant blend showing strong solubilization capacity, which accordingly gives high stability. Therefore, palm kernel 


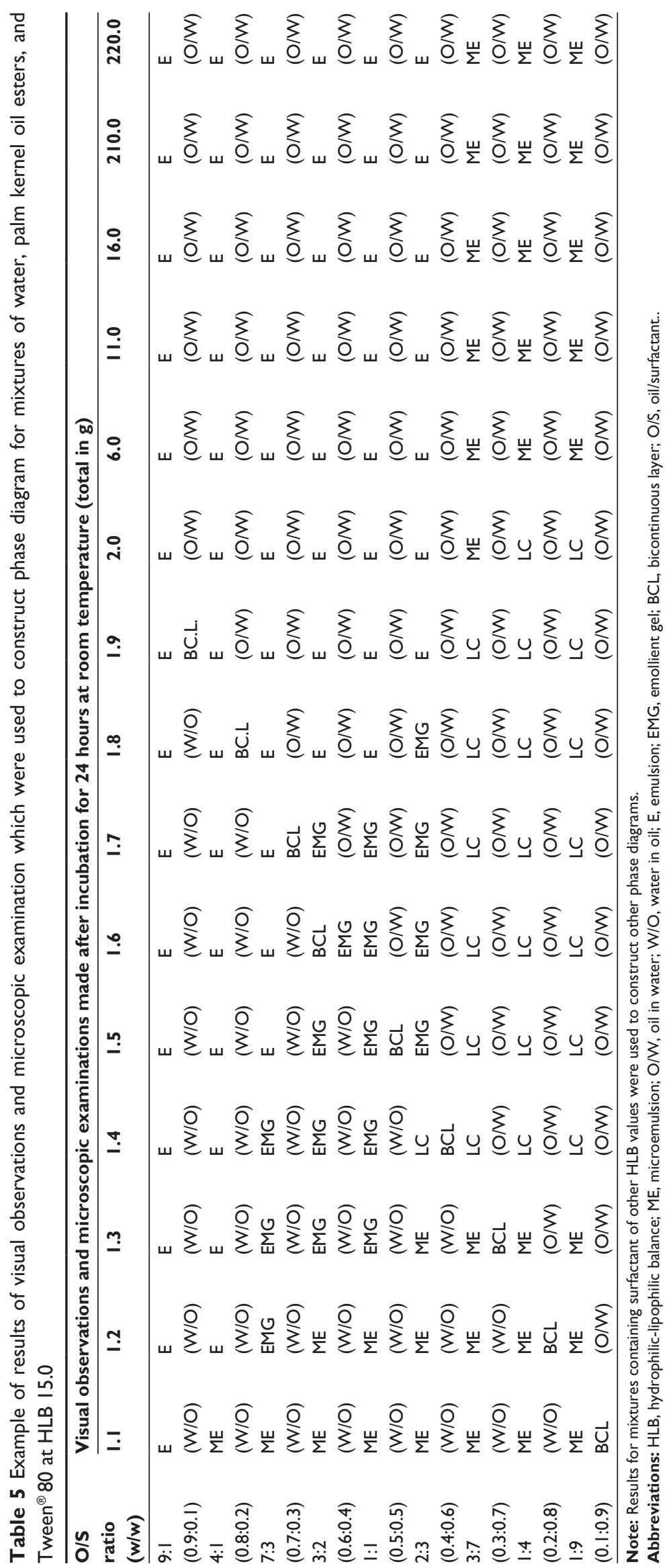


Table 6 The solubilization capacity of selected surfactants and surfactant blends

\begin{tabular}{lll}
\hline Surfactant & HLB & $\begin{array}{l}\text { The minimum \% of surfactant formed } \\
\text { reverse micelle (solubilization capacity } \\
\text { of surfactant to water) }\end{array}$ \\
\hline T20 & 16.7 & 36.4 \\
T60 & 14.9 & 27.3 \\
T80 & 15.0 & 18.2 \\
T85 & 11.0 & 27.3 \\
T80/S20 & 13.7 & 36.4 \\
T80/S60 & 14.0 & 36.4 \\
T80/S85 & 13.7 & 18.2 \\
T80/S80 & 13.9 & 27.3 \\
T80/S80 & 12.9 & 36.4 \\
T80/S80 & 11.8 & 36.4 \\
T80/S80 & 10.7 & 45.4 \\
\hline
\end{tabular}

Abbreviations: HLB, hydrophilic-lipophilic balance; T, Tween ${ }^{\oplus}$; S, Span ${ }^{\circledast}$.

oil esters might potentially improve the solubility of poorly oil-soluble drugs, specifically those with amphiphilic properties, such that they do not completely dissolve in either the oil phase or the aqueous phase. Such drugs would include the secondary plant metabolites, eg, tannins, flavonoids, and polyphenols.

\section{Pseudoternary phase diagrams}

Figure 2 shows a pseudoternary phase diagram for mixtures of palm kernel oil esters, Tween ${ }^{\circledR} 80$, and water at various component compositions. All types of dispersions, including conventional water-in-oil and oil-in-water emulsions, water-in-oil and oil-in-water microemulsions, bicontinuous and transitional liquid crystalline structures with high swelling capacity, can be formed by Tween ${ }^{\circledR} 80$ mixtures. A large area of clear isocratic solution (water-in-oil microemulsion) is

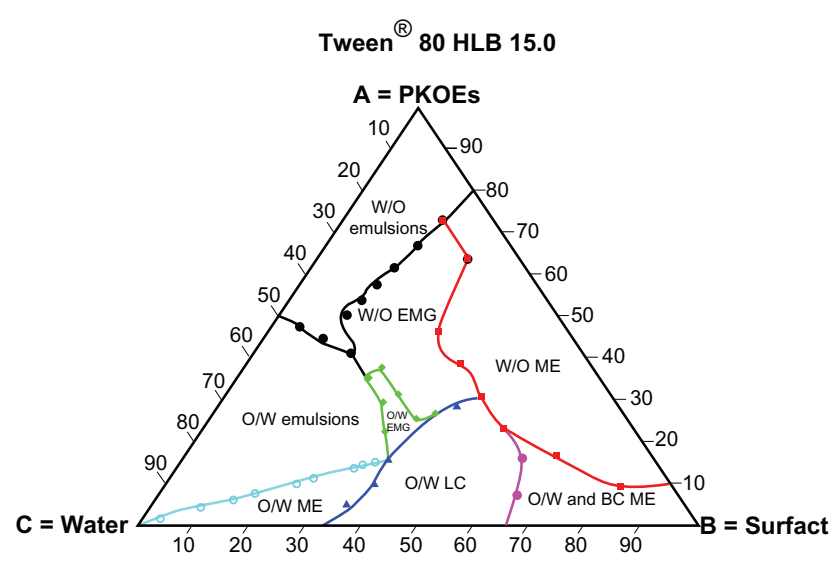

Figure 2 Complete schematic pseudoternary phase diagram formed by Tween ${ }^{\circledR} 80$ (HLB 15), palm kernel oil esters and water mixtures at various component compositions.

Abbreviations: HLB, hydrophilic-lipophilic balance; PKOEs, palm kernel oil esters; W/O, water-in-oil; EMG, emollient gel; ME, microemulsion; O/W, oil-in-water; LC, liquid crystalline; Surfact, surfactant. formed at the oil surfactant (palm kernel oil esters-surfactant) axis A-B in oil-rich regions. The minimum content of Tween ${ }^{\mathbb{R}}$ 80 at an HLB of 15.0 formed in an isocratic system is $18.2 \%$. This minimum content of surfactant in a microemulsion system is known as the surfactant solubilization capacity.22 The smaller the percentage of surfactant in a microemulsion system, the higher the solubilization capacity of the surfactant, the better the match of the oil and surfactant HLB, and hence the higher the stability of the product. Based on solubilization capacity, Tween ${ }^{\circledR} 80$ was selected as the best single surfactant from the Tween ${ }^{\circledR}$ series in Table 1.

The larger area of water-in-oil microemulsion formed by Tween ${ }^{\circledR} 80$ is due to the large molecular packing ratio of Tween ${ }^{\circledR} 80$, which is classified as a strong solubilizer. ${ }^{26}$ Recent research has also suggested that the solubilization capacity and formation of water-in-oil microemulsion is caused by the extent of packing at the interface and not because of the HLB or the specific hydrophobicity of the surfactants..$^{25}$ The large packing ratio for Tween ${ }^{\circledR} 80$ and palm kernel oil esters is due to the structural similarity between the oleyl group on the palm kernel oil esters and lipophilic tail (oleate group) of Tween $^{\circledR} 80$, as previously mentioned. This result is supported by work done by Gullapalli and Shath who showed that the formation of a reverse micelle system is due to the similarities between the lipophilic tail of the surfactant (Tween ${ }^{\circledR} 80$ ) and the oil phase. ${ }^{27}$ The present study had the same finding due to the similarity between the lipophilic tail of the surfactant and the oleyl group on the palm kernel oil esters. The second most important finding is the biocompatibility of the reverse micelle system produced by Tween ${ }^{\circledR} 80$ at a lower concentration (18.2\%) despite Tween ${ }^{\circledR} 80$ itself being highly safe. The main disadvantage of microemulsion systems is the lack of biocompatibility due to high surfactant(s) concentrations which might lead to toxicity or skin irritation. ${ }^{18}$ The use of palm kernel oil esters that form a reverse micelle system in any formulation can overcome the lack of biocompatibility of such microemulsion systems because a low concentration of surfactant (18.2\%) is used.

A bicontinuous system was also formed by Tween ${ }^{\circledR}$ 80 at an HLB of 15.0 and a surfactant concentration of $53.8 \%$, and continued downwards towards the surfactant vertex (B), reaching $81.8 \%$ (Figure 2). A bicontinuous system is one in which water-rich and oil-rich domains are separated by a surfactant-rich layer. ${ }^{18}$ This layer in the system of Tween ${ }^{\circledR} 80$, palm kernel oil esters, and water is formed between a large water-in-oil microemulsion layer and a small oil-in-water microemulsion layer at a minimum surfactant composition of $61.5 \%$. The boundary region of a 
water-in-oil-bicontinuous oil-in-water microemulsion has important applications for oral drug delivery when the drug involved is susceptible to enzymatic hydrolysis, ie, the system is expected to convert a microemulsion from water-in-oil to oil-in-water upon dilution in the small intestine. This may result in increased drug solubility and enhanced bioavailability. ${ }^{28}$ The area of oil-in-water microemulsion formed by this system (Figure 2) is smaller compared with the larger area of water-in-oil microemulsion. This is because of the lower dissolution behavior of the bulky polyoxyethylene group, which gives rise to dependence of the system on phase inversion temperature. ${ }^{22}$

A transitional liquid crystalline layer with high swelling capacity is one of the largest dispersion systems formed by Tween $^{\circledR} 80$, palm kernel oil esters, and water mixtures. This dispersion system is sandwiched between the water-in-oil microemulsion and the oil-in-water microemulsion areas at the surfactant-water axis in a water-rich region (Figure 2). The formation of this layer could be due to the hydrogen bonding between the hydroxyl group of the oxyethylene group of Tween $^{\circledR} 80$ and the hydroxyl group of water, which leads to the formation of highly sticky gel networks with high swelling capacity. This gel network is formed at a high surfactant concentration (Tween ${ }^{\circledR} 80$ ), hence the presence of many oxyethylene groups in the water-rich regions. The hydrogen bonding networks are gradually ruptured when diluted with water. The rupture of the liquid crystalline layer system when diluted with water indicates the presence and role of hydrogen bonding in the formation of liquid crystalline structures due to insufficient hydroxyl groups with the oxyethylene moiety compared with the excess of the water gradually added.

Transitional liquid crystalline systems have potential applications in topical ocular drug delivery. Transitional liquid crystalline systems can prolong precorneal retention time, which is important for drugs to be able to reach the therapeutic levels at the site of action, so could overcome one of the major problems in ocular drug delivery. ${ }^{18}$ The application of this dispersion phase might also be useful to solve some of the problems of conventional ocular drug delivery relating to drainage rate and precorneal loss factors, such as tear dynamics, nonproductive absorption, and transient residence time in the cul de sac, and hence could improve the bioavailability of ocular drug delivery. ${ }^{29}$

It is also noticeable that Tween ${ }^{\circledR} 80$ formed large conventional oil-in-water emulsion areas compared with waterin-oil emulsion on the oil-water axis. Water in oil emulsion occupied the upper part of the triangle (oil-rich region) towards the palm kernel oil ester vertex, whereas the oil-in-water emulsion is located at the lower part (water-rich region) towards the water vertex on the oil-water axis of the triangular diagram. The formation of conventional water-in-oil emulsion or oil-in-water emulsion depends on the composition of the emulsifier and its solubility in the oil and water. ${ }^{23}$ In this study, a larger area of conventional oil-in-water emulsion than water-in-oil emulsion is formed (Figure 2) due to the higher HLB of Tween ${ }^{\circledR} 80$ (ie, 15.0) and hence its good solubility in the continuous phase (water) which promotes the formation of oil-in-water emulsion. ${ }^{15}$ Conventional water-in-oil and oil-in-water emulsions have been used for a long time as drug carriers by the pharmaceutical industry, as well as in the cosmetics industry. ${ }^{30,31}$

The gel dispersion types formed by Tween ${ }^{\circledR} 80$, palm kernel oil esters, and water, are found in the central regions of the triangle phase diagrams. The gel systems included both water-in-oil organogel and oil-in-water organogel. The area of water-in-oil organogel is located at the upper middle part of the triangles in the oil-rich regions, whereas the oilin-water organogel is located in the lower middle part of the triangles towards the water-rich regions. The geometry of the water-in-oil organogel formed by Tween ${ }^{\circledR} 80$ is larger compared with the oil-in-water organogel. This can be explained by the mechanism of gel formation described by Kunieda et al, ${ }^{32}$ whereby an unstable oil-in-water blend is formed in the presence of a lipophilic nonionic surfactant at the same time as water-in-oil is formed inside small droplets of oilin-water, and is stabilized by lipophilic nonionic surfactants, hence, all water inside the oil phase is taken up, and a oil-inwater organogel is formed which is small in size compared with ordinary water-in-oil emulsion of the same system. ${ }^{32}$ In this study, the presence of hydrophilic surfactant Tween ${ }^{\circledR}$ 80 in oil-rich regions led to the formation of water-in-oil organogel inside small water droplets of water-in-oil emulsion compared with ordinary oil-in-water emulsion, which is stabilized by hydrophilic surfactant. Therefore, oil-in-water organogel is located in the lower middle triangle in the water-rich regions, and formed in smaller areas compared with water-in-oil organogel.

Figures 3-6 show the behaviors of surfactant blends of Tween ${ }^{\circledR} 80 / \operatorname{Span}^{\circledR} 80$ (with HLB values of 13.9 , 12.9, 11.8, and 10.7), palm kernel oil esters, and water at various concentration levels. The dispersion systems formed by these mixtures reflect the nature and behavior of their component compositions. The dispersion systems in these phase diagrams differ geometrically from Tween ${ }^{\circledR} 80$ phase diagram. They show much smaller areas of water-in-oil microemulsion compared with Tween ${ }^{\circledR} 80$ (HLB 15.0). They also show 


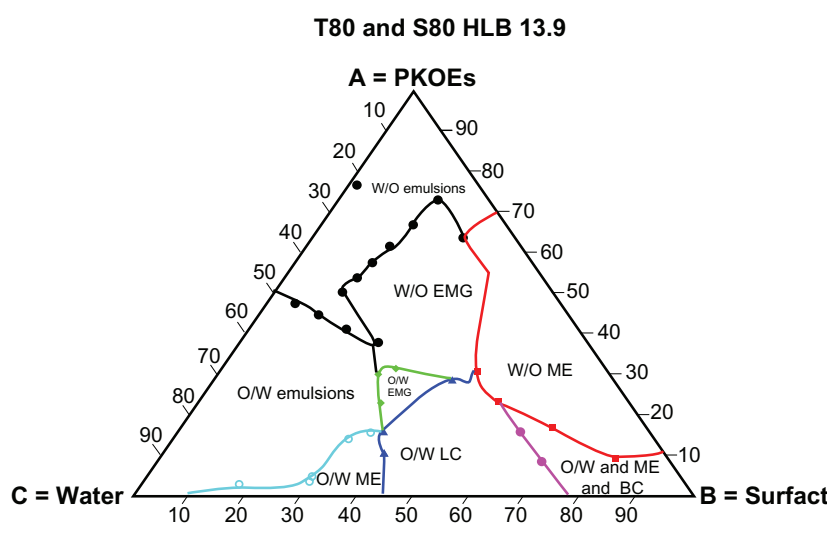

Figure 3 Complete schematic pseudoternary phase diagram formed by Tween ${ }^{\circledast} 80 /$ Span ${ }^{\circledR} 80$ blend at HLB 13.9, palm kernel oil esters and water at various component compositions.

Abbreviations: HLB, hydrophilic-lipophilic balance; PKOEs, palm kernel oil esters; W/O, water-in-oil; EMG, emollient gel; ME, microemulsion; O/W, oil-in-water; LC, liquid crystalline; Surfact, surfactant; T, Tween ${ }^{\circledR}$; S, Span ${ }^{\circledR}$

variation in area for the water-in-oil microemulsion system and other types of dispersion. Tween ${ }^{\circledR} 80 / \operatorname{Span}^{\circledR} 80$ blend at an HLB of 13.9 formed a large water-in-oil microemulsion area, followed by Tween ${ }^{\circledast} 80 / \mathrm{Span}^{\circledast} 80$ at HLBs of $12.9,11.8$, and 10.7 (Figures 3-6). The smaller area of water-in-oil microemulsion is due to a lower HLB, which increases the lipophilic character of the surfactant blend..$^{32}$ It is also clear from the solubilization capacity results that the Tween ${ }^{\circledR} 80 /$ $\mathrm{Span}^{\circledR} 80$ blend with an HLB of 13.9 is a stronger solubilizer for water in palm kernel oil esters than other blends of Tween ${ }^{6}$ 80/Span ${ }^{\circledR} 80$ with HLB values in the range of 12.9-10.7. The weak interaction between the oil and surfactant blends at lower HLB values for forming a reverse micelle system is due to the weaker solubilization of water at the interface in the presence of high percentages of lipophilic surfactant in the blends. This will lead to reduction of the large molecular

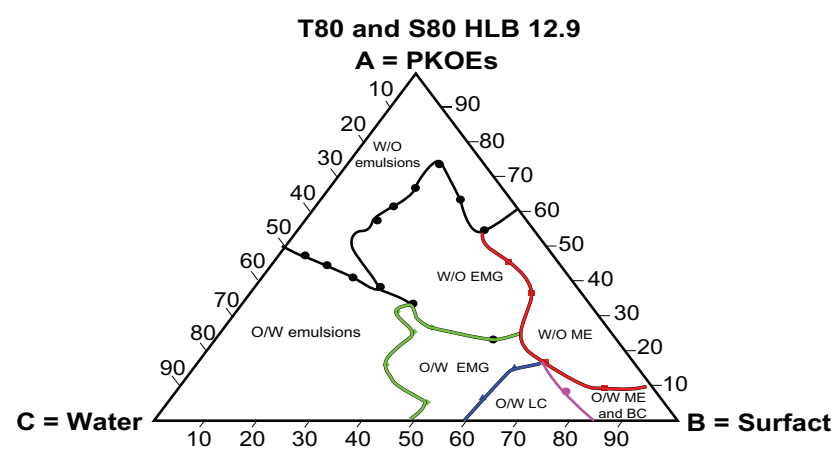

Figure 4 Complete schematic pseudoternary phase diagram formed by Tween ${ }^{\circledR} 80 /$ Span ${ }^{\circledR} 80$ blend at HLB 12.9, palm kernel oil esters and water at various component compositions.

Abbreviations: HLB, hydrophilic-lipophilic balance; PKOEs, palm kernel oil esters; W/O, water-in-oil; EMG, emollient gel; ME, microemulsion; O/W, oil-in-water; LC, liquid crystalline; Surfact, surfactant; T, Tween ${ }^{\circledR}$; S, Span ${ }^{\circledR}$.

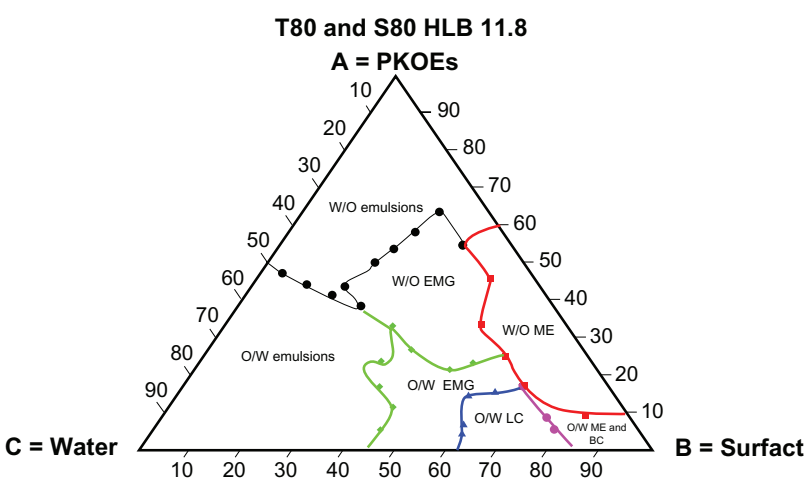

Figure 5 Complete schematic pseudoternary phase diagram formed by Tween ${ }^{\circledR}$ 80/ Span ${ }^{\circledR} 80$ blend at HLB I I.8, palm kernel oil esters and water at various component compositions.

Abbreviations: HLB, hydrophilic-lipophilic balance; PKOEs, palm kernel oil esters; W/O, water-in-oil; EMG, emollient gel; ME, microemulsion; O/W, oil-in-water; LC, liquid crystalline; Surfact, surfactant; T, Tween ${ }^{\circledR}$; S, Span ${ }^{\circledast}$.

packing ratio of Tween ${ }^{\circledR} 80$ due to its insufficient quantity, and hence results in a small area for the reverse micelle system. ${ }^{26}$

Figures 4-6 lack the dispersion phase for oil-in-water microemulsion after oil-in-water liquid crystalline formation, and this is replaced by a larger area of oil-in-water organogel, compared with Figures 2 and 3, as a result of the lower HLB values of the blends. The area of oil-in-water organogel is increased by the lower HLB values of the blends shown in Figures 2-6. This result is due to formation of water-in-oil emulsion inside small droplets of unstable oil-in-water emulsion, and are explained by the findings of Kunieda et al. ${ }^{32}$

The tendency of the lipophilic blend of Tween ${ }^{\circledR} 80 /$ $\operatorname{Span}^{\circledR} 80$ at an HLB of 10.7 to form a large area of conventional water-in-oil emulsion is shown in Figure 6. The areas of conventional water-in-oil emulsion decrease with

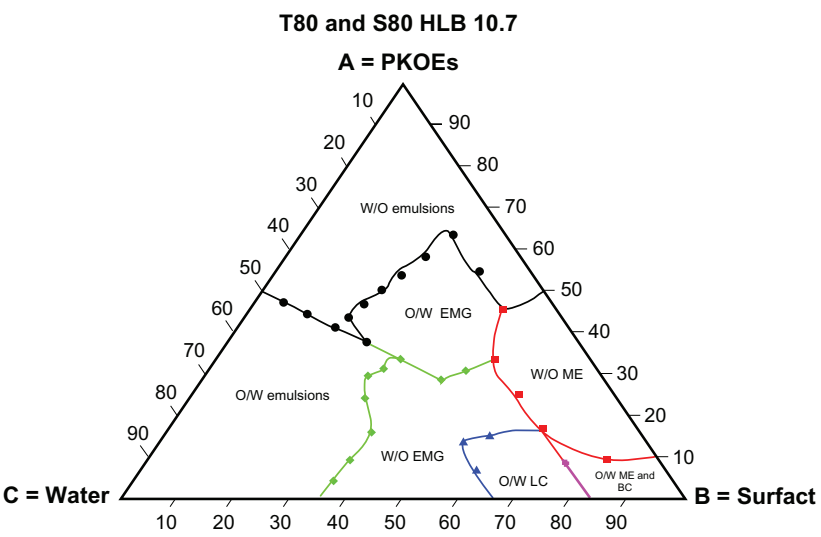

Figure 6 Complete schematic pseudoternary phase formed by Tween ${ }^{\circledR} 80 / \mathrm{Span} 80^{\circledR}$ blend at HLB 10.7, palm kernel oil esters, and water at various compositions.

Abbreviations: HLB, hydrophilic-lipophilic balance; PKOEs, palm kernel oil esters; W/O, water-in-oil; EMG, emollient gel; ME, microemulsion; O/W, oil-in-water; LC, liquid crystalline; Surfact, surfactant; T, Tween ${ }^{\circledR}$; S, Span ${ }^{\circledR}$. 


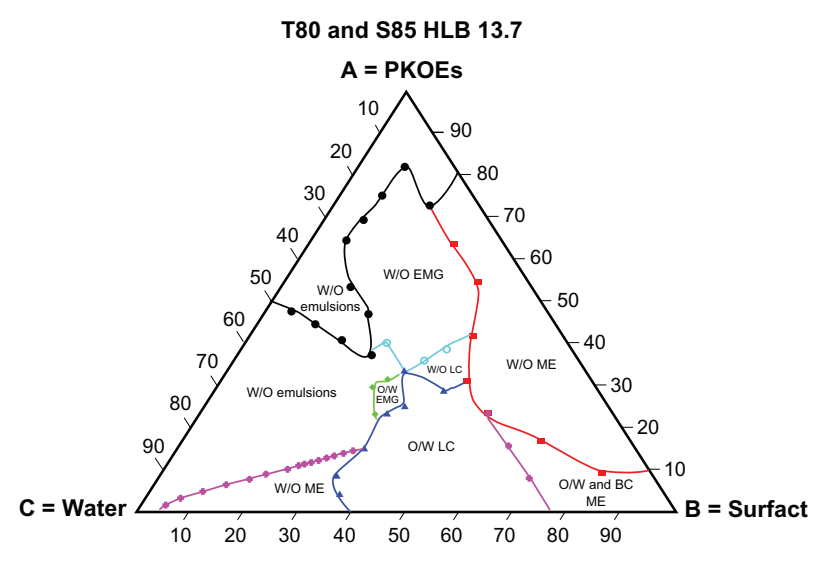

Figure 7 Complete schematic pseudoternary phase formed by Tween ${ }^{\circledR} 80 /$ Span ${ }^{\circledR} 85$ blend at HLB 13.7, palm kernel oil esters and water at various component compositions.

Abbreviations: HLB, hydrophilic-lipophilic balance; PKOEs, palm kernel oil esters; W/O, water-in-oil; EMG, emollient gel; ME, microemulsion; O/W, oil-in-water; LC, liquid crystalline; Surfact, surfactant; T, Tween ${ }^{\circledR}$; S, Span ${ }^{\circledR}$.

increasing the HLB in the Tween ${ }^{\circledR} 80 / \operatorname{Span}^{\circledR} 80$ blends, as shown in Figures 3-6. Similarly, a larger oil-in-water area is formed by the blend of Tween ${ }^{\circledR} 80 / \operatorname{Span}^{\circledR} 80$ at a higher HLB value (13.9), and this area decreases with blends having a lower HLB value (10.7). ${ }^{14,32}$

Figure 7 shows the phase diagram behavior of a Tween ${ }^{\circledR}$ $80 / \operatorname{Span}^{\circledR} 85$ blend at HLB 13.7. This blend of surfactants results in a phase diagram with features similar to those of the Tween ${ }^{\circledR} 80$ phase diagram. The major differences are the larger area of water-in-oil organogel and the smaller area of oil-in-water organogel, in addition to the formation of a waterin-oil liquid crystalline dispersion system which is completely absent in the phase diagram of Tween ${ }^{\circledR} 80$. The formation of this type of dispersion system in the blends of surfactants (Tween ${ }^{\circledR} 80 / \operatorname{Span}^{\circledR} 85$ ) indicates better coverage of Tween ${ }^{\circledR}$ $80 / \operatorname{Span}^{\circledR} 85$ at the interface, leading to the formation of a stable and identified water-in-oil liquid crystalline system in the presence of a hydrophilic-lipophilic blend of surfactants. This result shows the importance of not only the optimal HLB of the blend but also the type of surfactants in the blend.

\section{Conclusion}

Solubilization capacity appears to be useful as a criterion for the selection of a single surfactant and blends of surfactants. Our study shows the importance of selecting a surfactant with the proper HLB for specific oils, as well as the type of surfactant or surfactant blend. The structural similarity between the lipophilic tail of the surfactant and the oleyl group on the palm kernel oil ester is the key factor in the formation of these micelles. The study also shows the important role of the double bond at position 9 of the oleate group in stabilizing and solubilizing water in palm kernel oil esters and formation of reverse micelle systems. Similarly, the high degree of similarity between the fatty acid chains of palm kernel oil esters and the tail groups of nonionic surfactants result in less solubilization capacity of water in palm kernel oil esters. It is also shown that a better blend of surfactants is obtained when surfactants at lower and higher HLB are blended. The greater the difference between the hydrophilic and lipophilic surfactants, the better the coverage by blends at the interface. The study also shows the importance of the structural similarities between the lipophilic tails of the surfactant blends. The phase diagrams for mixtures of palm kernel oil esters with nonionic surfactants (Tween ${ }^{\circledR}$ and $\operatorname{Span}^{\circledR}$ series) and water constructed in this study have not been published before, thus would be very useful for researchers and manufacturers who are interested in this oil. The micelles discussed in this study have potential applications, advantages, and usefulness in the pharmaceutical industry as delivery systems by various routes of administration, as well as in cosmetics and personal care products.

\section{Acknowledgments}

We gratefully acknowledge the research grant received from Biotechnology Directorate, Malaysia, the financial support provided by Universiti Sains Malaysia for Elrashid, and the supply of the palm kernel oil esters by researchers from the Chemistry Department, Faculty of Sciences Universiti Putra Malaysia.

\section{Disclosure}

The authors report no conflicts of interest in this work.

\section{References}

1. Tang T, Teoh P. Palm kernel oil extraction - The Malaysian experience. J Am Oil Chem Soc. 1985;62(2):254-258.

2. Gunawan E, Basri M, Rahman M, Salleh A, Rahman R. Lipasecatalyzed synthesis of palm-based wax esters. J Oleo Sci. 2004;53(10): 471-477.

3. Sin K, Basri M, Rahman M, Salleh A, Rahman R, Ariff A. Optimization of palm-based wax esters production using statistical experimental designs. J Oleo Sci. 2005;54(10):519-528.

4. Keng P, Basri M, Zakaria M, et al. Newly synthesized palm esters for cosmetics industry. Ind Crops Prod. 2009;29(1):37-44.

5. Keng P, Basri M, Ariff A, Abdul Rahman M, Abdul Rahman R, Salleh A. Scale-up synthesis of lipase-catalyzed palm esters in stirred-tank reactor. Bioresource Technology. 2008;99(14):6097-6104.

6. Tan I, Kumar K, Theanmalar M, Gan S, Gordon III B. Saponified palm kernel oil and its major free fatty acids as carbon substrates for the production of polyhydroxyalkanoates in Pseudomonas putida PGA1. Appl Microbiol Biotechnol. 1997;47(3):207-211.

7. Young F. Palm kernel and coconut oils: Analytical characteristics, process technology and uses. J Am Oil Chem Soc. 1983;60(2):374-379.

8. Kalustian P. Pharmaceutical and cosmetic uses of palm and lauric products. J Am Oil Chem Soc. 1985;62(2):431-433. 
9. Ogiso T, Shintani M. Mechanism for the enhancement effect of fatty acids on the percutaneous absorption of propranolol. J Pharm Sci. 1990; 79(12):1065-1071.

10. Knaut J, Richtler H. Trends in industrial uses of palm and lauric oils. J Am Oil Chem Soc. 1985;62(2):317-327.

11. Radzi S, Basri M, Salleh A, et al. Large scale production of liquid wax ester by immobilized lipase. J Oleo Sci. 2005;54(4):203-209.

12. Shafiq-un-Nabi S, Shakeel F, Talegaonkar S, et al. Formulation development and optimization using nanoemulsion technique: A technical note. AAPS Pharm Sci Tech. 2007;8(2):12-17.

13. Sadoqi $\mathrm{M}, \mathrm{Lau}-\mathrm{Cam} \mathrm{CA}, \mathrm{Wu} \mathrm{SH}$. Investigation of the micellar properties of the tocopheryl polyethylene glycol succinate surfactants TPGS 400 and TPGS 1000 by steady state fluorometry. J Colloid Interface Sci. 2009;333(2):585-589.

14. Jiao J, Burgess D. Rheology and stability of water-in-oil-in-water multiple emulsions containing Span 83 and Tween 80. AAPS J. 2003; 5(1):62-73.

15. Yaghmur A, Campo L, Aserin A, Garti N, Glatter O. Structural characterization of five-component food grade oil-in-water nonionic microemulsions. Phys Chem Chem Phys. 2004;6(7):1524-1533.

16. Yuan Y, Li S-M, Mo F-K, Zhong D-F. Investigation of microemulsion system for transdermal delivery of meloxicam. Int J Pharm. 2006; 321(1-2):117-123.

17. Viyoch J, Klinthong N, Siripaisal W. Development of oil-in water emulsion containing tamarind fruit pulp extract I. Physical characteristics and stability of emulsion. Naresuan Univ J. 2003;11(3):29-49.

18. Alany RG, Rades T, Nicoll J, Tucker IG, Davies NM. W/O microemulsions for ocular delivery: Evaluation of ocular irritation and precorneal retention. J Control Release. 2006;111(1-2):145-152.

19. Aboofazeli R, Patel N, Thomas M, Lawrence M. Investigations into the formation and characterization of phospholipid microemulsions. IV. Pseudo-ternary phase diagrams of systems containing waterlecithin-alcohol and oil; the influence of oil. Int J Pharm. 1995;125(1): 107-116.

20. Santos P, Watkinson A, Hadgraft J, Lane M. Application of microemulsions in dermal and transdermal drug delivery. Skin Pharmacol Physiol. 2008;21(5):246-259.
21. Chan J, El Maghraby G, Craig J, Alany R. Effect of water-in-oil microemulsions and lamellar liquid crystalline systems on the precorneal tear film of albino New Zealand rabbits. Clin Ophthalmol. 2008;2(1): $129-138$.

22. Förster T, Von Rybinski W, Wadle A. Influence of microemulsion phases on the preparation of fine-disperse emulsions. Adv Colloid Interface Sci. 1995;58(2-3):119-149.

23. Golemanov K, Tcholakova S, Denkov N, Gurkov T. Selection of surfactants for stable paraffin-in-water dispersions, undergoing solid-liquid transition of the dispersed particles. Langmuir. 2006; 22(8):3560-3569.

24. Paul BK, Mitra RK. Water solubilization capacity of mixed reverse micelles: Effect of surfactant component, the nature of the oil, and electrolyte concentration. J Colloid Interface Sci. 2005;288(1): 261-279.

25. Porras M, Solans C, González C, Gutiérrez JM. Properties of water-in-oil (W/O) nano-emulsions prepared by a low-energy emulsification method. Colloids Surf A Physicochem Eng Asp. 2008;324(1-3):181-188.

26. Sjöblom J, Lindberg R, Friberg SE. Microemulsions - phase equilibria characterization, structures, applications and chemical reactions. Adv Colloid Interface Sci. 1996;65:125-187.

27. Gullapalli R, Sheth B. Influence of an optimized non-ionic emulsifier blend on properties of oil-in-water emulsions. Eur J Pharm Biopharm. 1999;48(3):233-238.

28. Rane SS, Anderson BD. What determines drug solubility in lipid vehicles: Is it predictable? Adv Drug Deliv Rev. 2008;60(6):638-656.

29. Kaur IP, Garg A, Singla AK, Aggarwal D. Vesicular systems in ocular drug delivery: An overview. Int J Pharm. 2004;269(1):1-14.

30. Marti-Mestres G, Nielloud F. Emulsions in health care applications - an overview. J Dispers Sci Technol. 2002;23(1):419-439.

31. Magdassi S. Delivery systems in cosmetics. Colloids Surf A Physicochem Eng Asp. 1997;123:671-679.

32. Kunieda H, Solans C, Shida N, Parra J. The formation of gel-emulsions in a water/nonionic surfactant/oil system. Colloids Surf. 1987;24(2-3): 225-237.
Drug Design, Development and Therapy

\section{Publish your work in this journal}

Drug Design, Development and Therapy is an international, peerreviewed open-access journal that spans the spectrum of drug design and development through to clinical applications. Clinical outcomes, patient safety, and programs for the development and effective, safe, and sustained use of medicines are a feature of the journal, which

\section{Dovepress}

has also been accepted for indexing on PubMed Central. The manuscript management system is completely online and includes a very quick and fair peer-review system, which is all easy to use. Visit http://www.dovepress.com/testimonials.php to read real quotes from published authors 